\title{
Genetic diversity analysis of isolates belonging to the Photobacterium phosphoreum species group collected from salmon products using AFLP fingerprinting ${ }^{\star}$
}

\author{
Jérôme Marc ${ }^{1}$, Macé Sabrina ${ }^{3}$, Dousset Xavier ${ }^{2}$, Pot Bruno ${ }^{4}$, Joffraud Jean-Jacques ${ }^{1, ~}$ \\ ${ }^{1}$ Ifremer, Laboratoire Ecosystèmes Microbiens et Molécules Marines pour les Biotechnologies (EM3B), \\ BP21105, 44311 Nantes, France \\ ${ }^{2}$ LUNAM Université, Oniris, UMR1014, Secalim, Nantes, France \\ ${ }^{3}$ University of Liège, Food Science Department, Fundamental and Applied Research for Animal and \\ Health, Food Microbiology, Sart-Tilman B43b, B-4000, Liège, Belgium \\ ${ }^{4}$ Applied Maths NV, Keistraat 120, Sint-Martens-Latem, Belgium \\ * Corresponding author : Jean-Jacques Joffraud, email address : joffraud@ifremer.fr
}

\begin{abstract}
:
An accurate amplified fragment length polymorphism (AFLP) method, including three primer sets for the selective amplification step, was developed to display the phylogenetic position of Photobacterium isolates collected from salmon products. This method was efficient for discriminating the three species Photobacterium phosphoreum, Photobacterium iliopiscarium and Photobacterium kishitanii, until now indistinctly gathered in the P.phosphoreum species group known to be strongly responsible for seafood spoilage. The AFLP fingerprints enabled the isolates to be separated into two main clusters that, according to the type strains, were assigned to the two species $P$. phosphoreum and $P$. iliopiscarium. $P$. kishitanii was not found in the collection. The accuracy of the method was validated by using gyrB-gene sequencing and luxA-gene PCR amplification, which confirmed the species delineation. Most of the isolates of each species were clonally distinct and even those that were isolated from the same source showed some diversity. Moreover, this AFLP method may be an excellent tool for genotyping isolates in bacterial communities and for clarifying our knowledge of the role of the different members of the Photobacterium species group in seafood spoilage.
\end{abstract}

\section{Highlights}

AFLP fingerprinting is a reliable tool for genotyping bacterial isolates. Diversity of bacterial isolates is shown by AFLP genotyping. The method allows the species delineation in the P. phosphoreum species group. Both $P$. iliopiscarium and $P$. phosphoreum are present in salmon products. 
Keywords : Photobacterium phosphoreum, AFLP, gyrB-gene, luxA-gene, Salmon products, Seafood spoilage

\section{Abbreviations}

- $\quad$ AFLP, amplified fragment length polymorphism;

- $\quad$ PCR, polymerase chain reaction;

- MAP, modified atmosphere packaging;

- SSO, specific spoilage organism;

- UPGMA, unweighted pair group with arithmetic mean;

- TTGE, temporal temperature gradient gel electrophoresis

\section{Footnote}

Note: Nucleotide sequence data reported are available in the EMBL database under the accession numbers LN715117 to LN715169 available from the European Nucleotide Archive (ENA) browser at http://www.ebi.ac.uk/ena/data/view/LN715117-LN715169 once they are released into the public domain. 


\section{Introduction}

Fresh fish products under modified atmosphere packaging (MAP) are sold increasingly and widely in Europe as chilled products. This type of packaging, enriched with a $\mathrm{CO}_{2}$ concentration usually varying between 20 and $60 \%$, extends the shelf life of these products by reducing the growth of some Gramnegative bacteria like Pseudomonas and Shewanella (Gram and Huss, 1996; Sivertsvik et al., 2002). The extended shelf life facilitates the transport, chilled distribution and marketing of fresh MAP fish. However, MAP favors the development of $\mathrm{CO}_{2}$-resistant bacteria, such as Gram-positive lactic acid bacteria, Brochothrix thermosphacta and the Gram-negative Photobacterium phosphoreum (Dalgaard et al., 1993; De la Hoz et al., 2000; Emborg et al., 2005; Hansen et al., 2009; Macé et al., 2012; Rudi et al., 2004). P. phosphoreum has been identified as the main specific spoilage organism (SSO) responsible for sensory spoilage of several chilled marine fish including salmon, cod, halibut, garfish, and saithe as well as shrimp (Dalgaard et al., 1993; Dalgaard, 1995; Emborg et al., 2002; Macé et al., 2013).

The genus Photobacterium is a member of the Vibrionaceae family and comprises facultatively aerobic, motile bacteria. They typically occur in seawater and are associated with marine animals such as saprophytes and enteric commensals (Urbanczyk et al., 2011). Many bacterial isolates identified as P. phosphoreum have been isolated from seafood products including fish. As a facultative psychrophile, this bacterium has been isolated from the surfaces and intestinal contents of fish generally occurring in cold meso-pelagic and bentho-pelagic habitats (Dunlap and Kita-Tsukamoto, 2006; Hastings and Nealson, 1981; Wilson et al., 2008) and consequently on fish fillets and steaks (Emborg et al., 2002; Hansen et al., 2009; Hovda et al., 2007; Macé et al., 2012; Reynisson et al.,2009; Rudi et al., 2004).

For many years, there has been ambiguity regarding the phylogenetic status, species composition and correct identification of strains in the $P$. phosphoreum species group. In a phylogenetic study based on multilocus sequence analysis targeting 16S rDNA, gyrB and lux ABFE genes, Ast and Dunlap (2005) demonstrated that strains originally isolated and identified as $P$. phosphoreum can be classified into three evolutionarily distinct lineages, considered species, $P$. phosphoreum, Photobacterium 
iliopiscarium and Photobacterium kishitanii. Regarded as sister species, $P$. phosphoreum and $P$. iliopiscarium are more closely related to each other than either is to P. kishitanii. These results were confirmed by Urbanczyk et al. (2011), reviewing the status of the genus Photobacterium from the perspectives of genomics, phylogeny and symbiosis. These authors carried out a phylogenetic analysis based on multiple housekeeping genes with both previously recognized and newly described species. The analysis revealed an evolutionary divergence within Photobacterium with the presence of two well-supported clades. The two clades separate luminous and symbiotic species from non-luminous, non-symbiotic forms. The type species of the genus is $P$. phosphoreum, a member of Clade 1 , while $P$. iliopiscarium is its closest relative in the phylogenetic tree. Species of Clade 1 are luminous with the exception of $P$. iliopiscarium, for which no luminous strains have been described to date. In order to identify these three species correctly and easily among the $P$. phosphoreum group, it is necessary to develop additional molecular methods.

Molecular genotyping tools, including amplified fragment length polymorphism (AFLP), enabling the fingerprinting of specific DNA patterns are used extensively to study microbial diversity (Cocolin and Ercolini, 2008; Giraffa and Neviani, 2001; Vos et al., 1995). For a set of bacterial isolates, phylogenetic relationships can be inferred by analyzing the AFLP data.

AFLP can be applied to DNA of any source or complexity, varying in both size and base composition and there are many applications for this universal marker system. Moreover, a high level of correlation between AFLP results and published DNA hybridization data has been shown for many bacterial genera and species, indicating that AFLP is a valuable technique for the classification of bacteria (Blears et al., 1998; Mougel et al., 2002). The method shows high discriminatory power and good reproducibility and has proved to be efficient for discriminating at the species level and below in various taxa (Janssen et al., 1996, Savelkoul et al., 1999). The development and application of AFLP as a fingerprinting method has led to significant progress in the study of the genetic diversity and taxonomy of bacteria (Cappello et al., 2008; Hamza et al., 2012; Lazzi et al., 2009; Lévesque et al., 2012; Nabhan et al., 2012). However, only a few studies have been published using AFLP to investigate the phylogeny of Photobacterium (Ast et al., 2007), most of them dealing with P. damselae 
in epidemiological surveys (Botella et al., 2002; Kvitt et al., 2002; Takahashi et al., 2008; Thyssen et al., 2000).

The aim of the present work is, including reference strains, to study the phylogenetic position of potential seafood spoiling Photobacterium isolates collected, during previous studies, from seafood products, especially salmon steaks (Macé et al., 2012, 2013a, 2013b) and cold-smoked salmon (Leroi et al., 1998). Here, we describe an accurate AFLP method to discriminate between P. phosphoreum and $P$. iliopiscarium, strains previously tentatively classified within the $P$. phosphoreum species group (Ast and Dunlap, 2005). The results are supported by investigating the gyrB-gene sequences and the presence or absence of the luxA gene in every isolate of the collection. As emphasized before (Ast and Dunlap, 2005), the taxonomic confusion surrounding P. phosphoreum exemplifies a fundamental problem in bacterial systematics: how can species that are phenotypically similar but evolutionarily distinct be reliably recognized and diagnosed? This work aims to contribute to resolving this problem.

\section{Materials and Methods}

\subsection{Bacterial strains}

Bacterial strains and isolates used in this study are listed in Table 1. Ten reference strains of Photobacterium were obtained from culture collections. They belong to the following species: $P$. angustum, $P$. damselae subsp. damselae, $P$. damselae subsp. piscicida, $P$. phosphoreum, $P$. iliopiscarium, P. kishitanii, P. indicum and P. lipolyticum. The Photobacterium isolates were collected from fish products, most of them from different batches of spoiled salmon steaks and a few from 
smoked salmon. These isolates were tentatively identified as belonging to the $P$. phosphoreum species group as described by Macé et al. (2012, 2013a, 2013b) and Leroi et al. (1998).

\subsection{DNA extraction}

Bacterial isolates or strains were cultured in enriched brain heart infusion broth (BHI; Biokar Diagnostics, Beauvais, France) supplemented with $2.0 \% \mathrm{NaCl}$ and incubated at $15^{\circ} \mathrm{C}$ for 24 to $48 \mathrm{~h}$ depending on the strain. The chromosomal DNA of all bacterial isolates was extracted using the Qiagen DNeasy blood and tissue kit (Qiagen, S.A., Courtaboeuf, France). DNA quality and quantity were determined using a NanoVue Plus ${ }^{\mathrm{TM}}$ spectrophotometer (GE Healthcare Europe, Germany) by measuring absorptions at 260 and $280 \mathrm{~nm}$.

\subsection{Amplified Fragment Length Polymorphism (AFLP) analysis}

Total genomic DNA from all Photobacterium strains and isolates listed in Table 1 were subjected to the AFLP Microbial Fingerprinting kit $\left(\right.$ AFLP $^{\circledR}$ Analysis System for Microorganisms, Invitrogen, Cergy Pontoise, France) according to the manufacturer's instructions. The Invitrogen ${ }^{\mathrm{TM}}$ protocol was slightly modified to accommodate the non-radioactive labeling of selective primers EcoRI-X and capillary electrophoresis.

\subsubsection{Preparation of primary template}

A restriction digestion mixture containing $5 \mathrm{X}$ reaction buffer $(50 \mathrm{mM}$ Tris- $\mathrm{HCl}, \mathrm{pH} 7.5,50 \mathrm{mM} \mathrm{Mg}$ acetate, $250 \mathrm{mM}$ K-acetate), $250 \mathrm{ng}$ of extracted bacterial DNA, $2.5 \mathrm{U}$ of EcoRI and MseI restriction enzymes in $2 \mu \mathrm{l}$ of buffer (10 mM Tris-HCl, pH 7.5, $50 \mathrm{mM} \mathrm{NaCl}, 0.1 \mathrm{mM}$ EDTA, $1 \mathrm{mM}$ DTT, 0.1 $\mathrm{mg} / \mathrm{ml} \mathrm{BSA}, 50 \%(\mathrm{v} / \mathrm{v})$ glycerol, $0.1 \%$ Triton X-100) and distilled water was prepared in a total volume of $25 \mu \mathrm{l}$ and incubated for $2 \mathrm{~h}$ at $37^{\circ} \mathrm{C}$. Then the mixture was incubated at $70^{\circ} \mathrm{C}$ for $15 \mathrm{~min}$ to inactivate the restriction endonucleases. After inactivation, $24 \mu 1$ of adapter ligation solution containing EcoRI/MseI adapters, $0.4 \mathrm{mM}$ ATP, $10 \mathrm{mM}$ Tris- $\mathrm{HCl}$ (pH 7.5), $10 \mathrm{mM}$ Mg-acetate, $50 \mathrm{mM}$ K-acetate and $1 \mu \mathrm{l}$ containing $1 \mathrm{U}$ of T4 DNA ligase, $10 \mathrm{mM}$ Tris- $\mathrm{HCl}(\mathrm{pH}$ 7.5), $1 \mathrm{mM}$ DTT, $50 \mathrm{mM}$ 
$\mathrm{KCl}, 50 \%$ glycerol $(\mathrm{v} / \mathrm{v})$ were added to the inactivated digestion solution and incubated at $20^{\circ} \mathrm{C}$ for $2 \mathrm{~h}$ to generate template DNA for amplification. Subsequently, a 1:10 dilution of the ligation mixture was prepared with TE buffer.

\subsubsection{Pre-amplification}

The "non-selective" primers EcoRI-0 and MseI-0 provided by the AFLP Microbial Fingerprinting kit were used for pre-amplification of the diluted primary template in a $20.4 \mu 1$ total volume according to the manufacturer's instructions. Pre-selective PCR was carried out in $20.4 \mu 1$ reaction mixtures containing $2 \mu \mathrm{l}$ of the diluted primary template described previously, $1.08 \mu \mathrm{l}$ of pre-selective EcoRI-0 primer $(27.8 \mathrm{ng} / \mu \mathrm{l}), 4.8 \mu \mathrm{l}$ of a mixture containing $M$ seI-0 primers $(6.7 \mathrm{ng} / \mu \mathrm{l})$ and $\mathrm{dNTPs}, 2 \mu \mathrm{l}$ of $10 \mathrm{X}$ PCR buffer plus Mg, and $0.4 \mu \mathrm{l}$ of Taq polymerase completed with distilled water. The reaction was subjected to the following PCR conditions: 20 cycles consisting of $30 \mathrm{~s}$ denaturation at $94^{\circ} \mathrm{C}, 60 \mathrm{~s}$ annealing at $56^{\circ} \mathrm{C}$ and $60 \mathrm{~s}$ extension at $72^{\circ} \mathrm{C}$. Amplifications were performed in a Bio-Rad thermal cycler (BioRad, Marne-la-Coquette, France). Subsequently, the pre-amplification product was diluted 50:1 in TE buffer (10 mM Tris-HCl, $0.1 \mathrm{mM}$ EDTA, $\mathrm{pH}$ 8.0).

\subsubsection{Selective PCR-amplification}

Fluorescent dye-labeled EcoRI-X primers (WellRED ${ }^{\mathrm{TM}}$, purchased from Sigma-Aldrich ${ }^{\circledR}$, Paris, France) and unlabeled selective primers $M s e \mathrm{I}-\mathrm{X}$ from the Invitrogen ${ }^{\mathrm{TM}}$ kit were used. These primers containing adjacent nucleotides $(\mathrm{X}=\mathrm{A}, \mathrm{C}, \mathrm{G}$ or $\mathrm{T})$ were tested for optimization and selected in preliminary tests among primers provided by the AFLP Microbial Fingerprinting kit (Invitrogen), as described in the next section "Selective primer combinations".

Selected primers were used for the selective amplification of the diluted pre-amplification product (5 $\mu \mathrm{l})$ in a $20 \mu \mathrm{l}$ total volume containing $4.5 \mu \mathrm{l}$ of a mixture of $M s e \mathrm{I}-\mathrm{X}$ selective primer $(6.7 \mathrm{ng} / \mu \mathrm{l})$ and dNTPs, $0.5 \mu$ l of labeled EcoRI-X selective primer, $2 \mu \mathrm{l}$ of 10X PCR buffer, and $0.1 \mu \mathrm{l}$ of Taq polymerase completed with distilled water. The selective PCR amplification profile was the following: 
13 cycles $\left(94^{\circ} \mathrm{C}-30 \mathrm{~s}, 65^{\circ} \mathrm{C}\right.$ to $\left.56^{\circ} \mathrm{C}-30 \mathrm{~s}, 72^{\circ} \mathrm{C}-60 \mathrm{~s}\right)$ of touch-down amplification with a $0.7^{\circ} \mathrm{C}$ decrease in the annealing temperature at each cycle followed by 23 identical cycles $\left(94^{\circ} \mathrm{C}-30 \mathrm{~s}, 56^{\circ} \mathrm{C}\right.$ $-30 \mathrm{~s}, 72^{\circ} \mathrm{C}-60 \mathrm{~s}$ ). Amplifications were performed in a Bio-Rad thermal cycler (BioRad, Marne-laCoquette, France).

\subsubsection{Selective primer combinations}

Sixteen combinations of "selective" primers, EcoRI-X and MseI-X, containing one additional adjacent nucleotide ( $\mathrm{X}=\mathrm{A}, \mathrm{C}, \mathrm{G}$ or $\mathrm{T}$ ) can potentially be used. According to the kit manufacturer's recommendation for bacteria, the following pairs of selective primers were first evaluated for optimization: EA-MA (EcoRI-A and MseI-A), EC-MA, EC-MC, EC-MT, EC-MG and ET-MA. These preliminary tests were performed on isolates 1 to 33 and strains R1 to R10 (Table 1) for EC-MG, ECMC, EC-MA and EC-MT. EA-MA and ET-MA were tested on reference strains R1 to R10 only. Finally, three selective primer pairs, EC-MC, EC-MA and EA-MA, were selected, based on the quality of the peaks produced (peak intensity, peak distribution and reproducibility of results) to study the genetic diversity of the isolates in relation to reference strains.

\subsubsection{Fragment analysis}

DNA amplified fragments were separated by capillary electrophoresis in the CEQ ${ }^{\mathrm{TM}} 8000$ DNA analysis system (Beckmann Coulter, Villepinte, France): $0.5 \mu$ l volume of selective PCR product and $0.5 \mu 1$ of DNA internal size standard (CEQ DNA size standard 600, Beckmann Coulter) were added to $30 \mu \mathrm{l}$ of sample loading solution (Beckmann Coulter). Samples were loaded onto the CEQ ${ }^{\mathrm{TM}} 8000$ system and run under the conditions specified by Beckmann Coulter. A DNA fingerprint was obtained for each primer pair tested and each sample. On this electropherogram, DNA fragments were identified according to their size (number of nucleotides). The scoring of the peaks generated was automated by analyzing the results with the 'fragment analysis module' of the CEQ 8000 software (CEQ ${ }^{\mathrm{TM}} 8000$ Genetic Analysis System V8). 
A minimum fluorescence threshold value of 1500 RFU (Relative Fluorescence Units) was chosen on the basis of the preliminary experiments. However, each DNA fingerprint was thoroughly reviewed, especially for high molecular weight lower peaks. If not considered by the automatic data analysis, they were included in the data set of peaks if their resolution was comparable to those of ladder fragments of similar size.

DNA fragments from 60 to 640 nucleotides were included in the study in order to generate a peak table. Peak table files, containing fragments of $60-640 \mathrm{bp}$, were transferred to the BioNumerics 7.1 software (Applied Maths NV, Sint-Martens-Latem, Belgium). For each of the three selected combinations of primer pairs, a pairwise comparison of fragment patterns was carried out by calculating a similarity matrix using the Dice coefficient. The resulting similarity matrix was regrouped by unweighted pair group clustering using arithmetic averages (UPGMA). Finally, using the same software, results from the three combinations were combined to display genotype relationships between the isolates studied. This was done by averaging the three similarity matrices and generating a single UPGMA dendrogram. The cophenetic correlation was calculated between the original similarity matrix and the similarity matrix recomposed from the UPGMA tree. This enabled the reliability of the individual branching levels in the dendrogram to be estimated. The repeatability of the AFLP methodology was investigated on three different strains of $P$. phosphoreum and three different strains of P. iliopiscarium, including the type strains of both species. DNA was extracted from each strain in three independent assays. The 18 AFLP patterns generated were analyzed in a single dendrogram using the Dice similarity coefficient, followed by UPGMA clustering. For each isolate, repeatability was determined as the similarity value between the three replicates. Then, the six values were averaged to obtain the mean repeatability, used as a threshold to define identical genotypes.

\section{4. luxA-gene PCR amplification}

Chromosomal DNA of isolates of the $P$. phosphoreum strain group was analyzed by PCR to detect the luxA gene. The absence of this gene enabled $P$. iliopiscarium to be discriminated from $P$.

phosphoreum and P. kishitanii (Ast and Dunlap, 2005). The P. phosphoreum-specific luxA primer pair 
Af/Ar was used to amplify the luxA region (about $750 \mathrm{bp}$ ) simultaneously with the gyrB gene using the 22f/1240r primer pairs in a duplex PCR. Both primer pairs were described by Ast and Dunlap (2004). After optimization of the annealing temperature, the following amplification protocol was performed: initial denaturing at $95^{\circ} \mathrm{C}$ for $3 \mathrm{~min} ; 35$ cycles of denaturing at $95^{\circ} \mathrm{C}$ for $1 \mathrm{~min}$, annealing at $53^{\circ} \mathrm{C}$ for $1 \mathrm{~min}$, extension at $72^{\circ} \mathrm{C}$ for $1.5 \mathrm{~min}$; one cycle at $72^{\circ} \mathrm{C}$ for $7 \mathrm{~min}$; snap cooling to $12^{\circ} \mathrm{C}$. The size of the PCR products was determined in a 1.8\% (w/v) agarose gel (Invitrogen) using a 502000 bp low range DNA Ladder (exACTGene, Fisher BioReagents, Fisher Scientific International Inc.).

2.5. gyrB-gene amplification, sequencing and phylogenetic analysis

The gyrB sequences of isolates and reference strains belonging to the Photobacterium genus were determined in this study. Two extra gyrB sequences from GenBank were included in this data set, one sequence of Photobacterium aquimaris BS-1 (JQ229762.1) (Urbanczyk et al., 2012) for its genetic proximity to the three species $P$. phosphoreum, $P$. kishitanii and $P$. iliopiscarium, and one of Photobacterium angustum ATCC 33975 (AY900627.1) to create an out-group. Amplification of gyrB (approximately 1200 nucleotides) was performed according to the protocol described by Dunlap and Ast (2005). The gyrB product was sequenced with an automated sequencer (Beckman Coulter Genomics, Takeley, UK) using the amplification primers 22f/1240r and the internal primers ili609f (GAAGGTTATTCAAAGAAAGC) and ili602r (CTTTGAATAACCTTCTTTATCC) designed for this study. The four resulting sequences were assembled into a unique contig with the BioEdit sequence alignment software (Hall, 1999).

A multiple alignment of the 1211 bp sequences was performed using the MEGA software package (version 6) (Tamura et al., 2013). It was verified by comparison with an alignment of the corresponding amino acids. After visual inspection, the 5' region of $671 \mathrm{bp}$ was kept for further analysis and the highly conserved, less informative region in 3' was discarded. Phylogenetic analyses were also carried out with the MEGA software: phylogenetic distances were calculated using the Kimura-2 correction. A neighbor-joining dendrogram (Saitou and Nei, 1987) was constructed and a bootstrapping analysis was performed using 1000 bootstrap replicates. 


\section{Results}

After preliminary experiments using six primer combinations (EA-MA, EC-MA, EC-MC, EC-MT, EC-MG and ET-MA), based on the number of fragments and their size distribution, three combinations were shown to be successful with all isolates or strains tested: EC-MC, EC-MA and EAMA. Experiments performed with EA-MA displayed the largest number of fragments with an average of 67 (35 to 140) compared to the other combinations with 39 (22 to 72 ) and 34 (20 to 71 ) for EC-MA and EC-MC, respectively. The majority of the fragments (>90\%) ranged in size from 60 to $350 \mathrm{bp}$. Using the Dice coefficient (optimization: $0.1 \%$, tolerance: $0.1 \%$ ) for pairwise similarity calculation and UPGMA as a clustering method, the main clusters were roughly delineated in the same way for the three primer combinations with the exception of only a few isolates (data not shown). Congruence between the three combinations estimated by Pearson correlation of the homologous pairwise similarities was 70.5, 76.1 and 75.1 for the EC-MC/EC-MA, EC-MA/EA-MA, and EC-MC/EA-MA couples, respectively. The UPGMA clustering, calculated from the overall similarity matrix obtained from the comparison of the individual matrices from the three combinations, is represented in Fig. 1 .

Isolates previously identified as belonging to the $P$. phosphoreum species group were delineated in two main clusters at a cut-off level of $40 \%$ similarity: cluster I (43 isolates) and cluster II (11 isolates), respectively. These clusters were strongly delineated, with cophenetic correlation coefficients of 92 and 95\%, respectively. Each of these two clusters was divided into two subclusters grouping at a cutoff level of above $60 \%$ similarity: IA (15 isolates), IB (28 isolates), IIA (8 isolates), and IIB (3 isolates). The type strain P. phosphoreum CIP $102511^{\mathrm{T}}$ was included in cluster I and P. iliopiscarium DSM9896 ${ }^{\mathrm{T}}$ in cluster II. Reference strains R2 (CCUG16288), previously identified as $P$. phosphoreum, R5 (P. kishitanii, CIP104260) and R4 (type strain of P. kishitanii LMG23890 ${ }^{\mathrm{T}}$ ) grouped together at 59\% similarity (cophenetic correlation of 91\%). With the exception of reference strain R10 (P. lipolyticum $\mathrm{LMG} 23071^{\mathrm{T}}$ ), all other reference strains were clearly out-grouped (similarity below $30 \%$, cophenetic coefficient of $94 \%$ ). According to these results, it can be assumed that cluster I isolates all belong to P. phosphoreum and cluster II isolates to P. iliopiscarium. 
Similarity values obtained between replicates ranged between $96.3 \%$ and $82.3 \%$ with an average value of $87.1 \%$. According to this mean value, nineteen isolates might be clonally related. Most of them were isolated from the same batch of salmon (Fig. 1): J4C12, J8C5, J4C13 (genotype a) and J7C2, $\mathrm{J} 7 \mathrm{C} 4$, J7C1 (genotype b) from batch G, as well as J4C1, J7C5, J4C2, J7C13, J7C14 (genotype f) and J3C17, J4C4 (genotype g) from the same batch G; MIP2566, MIP2567 (genotype c) and MIP2562, MIP2563 (genotype e) from batch D; only MIP2569 and MIP2583 (genotype d) were isolated from two different batches, D and E.

To support these findings, luxA-gene PCR detection and gyrB-gene sequencing were performed. lux $\mathrm{A}$ and $g y r \mathrm{~B}$ genes were co-amplified in a single multiplex PCR in which the $g y r \mathrm{~B}$ gene was the internal PCR control. The luxA gene was missing in all 11 isolates from cluster II of the AFLP analysis (Fig. 1), while the gene was confirmed in all other isolates of cluster I and reference strains R1, R2 and R4, R5, supposedly belonging to P. phosphoreum and P. kishitanii, respectively. The luxA-gene amplification results are summarized in Table 1.

The gyrB gene of isolates and reference strains R1 (P. phosphoreum, CIP102511 $\left.{ }^{\mathrm{T}}\right), \mathrm{R} 2(P$. phosphoreum, CCUG16288), R3 (P. iliopiscarium, DSM9896 ${ }^{\mathrm{T}}$ ), R4 and R5 (P. kishitanii, LMG23890 ${ }^{\mathrm{T}}$ and CIP104260, respectively) was amplified and sequenced. Sequence analysis using the neighbor-joining method, with the Kimura-2 correction, resulted in the phylogenetic tree shown in Fig. 2. The tree displays three distinct groups with high bootstrap values around the three type strains of $P$. phosphoreum, P. kishitanii and P. iliopiscarium. Genetic distances between the P. kishitanii group and the groups of P. phosphoreum and P. iliopiscarium are $12 \%$ and $12.9 \%$, respectively. The distance between $P$. phosphoreum and P. iliopiscarium is $6.2 \%$. Within the groups, similarity is $99.5 \%$ (98100) for the P. phosphoreum group, $99.5 \%$ (98.9 - 100) for the P. iliopiscarium group and $98 \%$ (96.9 - 100) for the $P$. kishitanii group. These three species show a genetic distance of at least $10.1 \%$ with $P$. aquimaris and a genetic distance of at least $19.8 \%$ with $P$. angustum. As anticipated, the P. kishitanii reference strain CIP104260 was found to be identical to the P. kishitanii type strain. The strain CCUG16288 clustered with this group at around 97\% similarity. 


\section{Discussion}

According to the AFLP study, 43 isolates were identified as $P$. phosphoreum and 11 isolates as $P$. iliopiscarium, which is completely supported with the findings obtained from the luxA-gene analysis and gyrB-gene analysis. Indeed, the gyrB-gene sequenced $P$. phosphoreum isolates fell into cluster I, together with the type strain P. phosphoreum CIP102511 ${ }^{\mathrm{T}}$. The gyrB-gene P. iliopiscarium isolates, with their type strain DSM9896 ${ }^{\mathrm{T}}$, could be assigned to cluster II. Both clusters corresponded to the separation observed in the AFLP analysis (Fig. 1) and also corroborated the finding of the luxA gene in $P$. phosphoreum and P. kishitanii but not in P. iliopiscarium. We have thus confirmed the results of Ast et al. (2005), that the absence of luxA distinguishes $P$. iliopiscarium from P. phosphoreum and $P$. kishitanii and this absence is consistent with the inability of the $P$. iliopiscarium isolates to produce luminescence.

From the AFLP results, it can be concluded that strains from the same Photobacterium species share at least $45 \%$ similarity, while less than $45 \%$ similarity suggests that isolates belong to different species of the genus Photobacterium. In addition, the reproducibility of the AFLP technology could be used to estimate the similarity between closely related isolates or strains from Photobacterium. The average similarity value obtained between replicates can be used as a threshold to define identical or clonaly related isolates belonging to the same AFLP genotype. Isolates included in the same AFLP genotype were shown to be $100 \%$ similar in the gyrB-gene sequence analysis (Fig. 2).

Reference strain R2 (CCUG16288), previously identified as $P$. phosphoreum, was found according to the gyrB-gene sequencing and the AFLP analysis, to belong to P. kishitanii. Since this strain, also named strain 455 or ATCC35081, was isolated by Baumann (Reichelt and Baumann, 1973) before the description of $P$. kishitanii, it clearly needs to be reclassified as $P$. kishitanii.

Interestingly, in a previous study, MIP encoded isolates were analyzed by temporal temperature gradient gel electrophoresis (TTGE) and the pattern of MIP2472 and MIP2478, now identified as $P$. iliopiscarium isolates was clearly different from those of the other P. phosphoreum isolates (data not shown). The hypothesis of their species difference was confirmed here. 
AFLP technology is generally considered a powerful technique for the identification of strains related at the species level. For Vibrionaceae, this method has been applied extensively to the genus Vibrio (Arias et al., 1997; Beaz-Hidalgo et al., 2008; Tao et al., 2012; Thompson et al., 2001) but only to two species of the genus Photobacterium: P. damselae (Botella et al., 2002; Kvitt et al., 2002; Takahashi et al., 2008; Thyssen et al., 2000) and P. kishitanii (Ast et al., 2007). In most of these studies, the restriction enzyme pair TaqI/HindIII was used, with only one primer set for the selective amplification. The enzymes EcoRI/MseI, used in the present work, have previously been applied with several primer sets for selective amplification in the studies of Ast et al. (2007) and Takahashi et al. (2008).

As stated by Ast and Dunlap (2005), until recent years, due to the previous inability to distinguish the three species within the $P$. phosphoreum species group, the ecological distribution of $P$. phosphoreum and P. iliopiscarium was poorly known. P. phosphoreum is commonly isolated from the intestine and skin of marine fish, incubated at low temperatures. P. iliopiscarium has been recovered from the intestines of species of cold-water fish and from samples of spoiled packaged fish stored under modified atmosphere at low temperature (Urbanczyk et al., 2011). In this study, all the isolates were picked from different salmon products during studies monitoring the microbial quality of raw salmon (Macé et al., 2012, 2013b) and cold-smoked salmon (Leroi et al., 1998). P. kishitanii did not occur among this set of isolates studied. This species, known to be a specific and exclusive bioluminescent symbiont of many different deep-sea fish, has also been encountered on warm-water fish skin (Ast and Dunlap, 2005).

To our knowledge, $P$. kishitanii has never been listed in the literature as occurring on cold or temperate seawater fish, except in a recent work on food-specific bacterial communities associated with meat and seafood spoilage (Chaillou et al., 2014). In that study, a metagenomic approach was 
used in which $P$. kishitanii was demonstrated to be part of the core seafood community i.e. occurring in cod fillet, salmon fillet and cold-smoked salmon.

The $P$. phosphoreum species group has been identified as the main SSO responsible for sensory spoilage of several chilled marine seafoods (Dagaard et al., 1993; Dalgaard, 1995; Emborg et al., 2002; Macé et al., 2013a). However, due to the inability until recent years to distinguish $P$. phosphoreum and P. iliopiscarium, their respective spoilage potential has never been studied. Some strains of the $P$. phosphoreum species group used in the present study have been assessed in our laboratory for their spoilage potential. Five strains previously isolated from cold-smoked salmon, identified as $P$. phosphoreum in the present study, have been shown to be spoiling bacteria when inoculated on sterile cold-smoked salmon (Joffraud et al., 2001, 2006; Stohr et al., 2001). In a recent work, Macé et al. (2013a) studied the spoilage potential of a mixture of four strains of Photobacterium, two P. phosphoreum and two P. iliopiscarium strains according to the present study. The mixture was spoiling but, as the strains were tested together, we cannot conclude about the respective spoilage behavior of the two species. Further studies are necessary to resolve this point.

\section{Conclusion}

In this work, an AFLP analysis was implemented on a collection of isolates recovered from various salmon products. In order to evaluate its robustness, three primer sets were used for the selective amplification step. As for other bacterial genera reported in the literature, AFLP was confirmed as a powerful technique for the delineation of isolates, related beyond species level, of the genus Photobacterium. The method also detected clonally related isolates belonging to the same AFLP genotype. The AFLP method was shown to distinguish clearly P. phosphoreum and P. iliopiscarium, two species that were previously difficult to discriminate with other than highly specialized phylogenetic studies. This discrimination was supported and validated by gyrB-gene sequence analysis and by the presence or absence of the luxA gene. Only a few isolates have previously been studied for their ability to spoil salmon products and the respective spoilage behavior of these two species was not clarified. Thus, the AFLP method presented here could be an excellent tool for genotyping isolates 
recovered from bacterial communities associated with seafood spoilage and shedding light on the role of the different members of the Photobacterium species group in seafood deterioration. 


\section{References}

Arias, C.R., Verdonck, L., Swings, J., Garay, E., Aznar, R., 1997. Intraspecific differentiation of Vibrio vulnificus biotypes by amplified fragment length polymorphism and ribotyping. Applied and Environmental Microbiology 63 (7), 2600-2606.

Ast, J.C., Dunlap, P.V., 2004. Phylogenetic analysis of the lux operon distinguishes two evolutionarily distinct clades of Photobacterium leiognathi. Archives of Microbiology 181, 352-361.

Ast, J.C., Dunlap, P.V., 2005. Phylogenetic resolution and habitat specificity of the Photobacterium phosphoreum species group. Environmental Microbiology 7, 1641-1654.

Ast, J.C., Cleenwerck, I., Engelbeen, K., Urbanczyk, H., Thompson, F.L., De Vos, P., Dunlap, P.V., 2007. Photobacterium kishitanii sp. nov., a luminous marine bacterium symbiotic with deep-sea fishes. International Journal of Systematic and Evolutionary Microbiology 57, 2073-2078.

Beaz-Hidalgo. B., Cleenwerck, I., Balboa, S., De Wachter, M., Thompson, F.L., Swings, J., De Vos, P., Romalde, J., 2008. Diversity of Vibrios associated with reared clams in Galicia (NW Spain). Systematic and Applied Microbiology 31, 215-222.

Blears, M.J., De Grandis, S.A., Lee, H., Trevors, J.T., 1998. Amplified fragment length polymorphism (AFLP): a review of procedure and its applications. Journal of Industrial Microbiology and Biotechnology 21, 99-114.

Botella, S., Pujalte, M.J., Macian, M.C., Ferrus, M.A., Hernandez, J., Garay, A., 2002. Amplified fragment length polymorphism (AFLP) and biochemical typing of Photobacterium damselae subsp. damselae. Journal of Applied Microbiology 93, 681-688.

Cappello, M.S., Stefani, D., Grieco, F., Logrieco, A., Zapparoli, G., 2008. Genotyping by Amplified Fragment Length Polymorphism and malate metabolism performances of indigenous Oenococcus oeni strains isolated from Primitivo wine. International Journal of Food Microbiology 127, 241-245. 
Chaillou, S., Chaulot-Talmont, A., Caekebeke, H., Cardinal, M., Christieans, S., Denis, C., Desmonts M.H., Dousset X., Feurer C., Hamon E., Joffraud J.J., La Carbona S., Leroi F., Leroy S., Lorre S., Macé S., Pilet M.F., Prévost H., Rivollier M., Roux D., Talon R., Zagorec M., Champomier-Vergès M.C., 2015. Origin and ecological selection of core and food-specific bacterial communities associated with meat and seafood spoilage. The ISME Journal 9, 1105-1118.

Cocolin, L., Ercolini, D., (Eds.) Molecular techniques in the microbial ecology of fermented foods. Springer 2008.

Dalgaard, P., Gram, L., Huss, H.H., 1993. Spoilage and shelf-life of cod fillets packed in vacuum or modified atmospheres. International Journal of Food Microbiology 19, 283-294.

Dalgaard, P., 1995. Modelling of microbial activity and prediction of shelf life for packed fresh fish. International Journal of Food Microbiology 26, 305-317.

De la Hoz, L., Lopez-Galvez, D.E., Fernandez, M., Hierro, E., Ordonez, J.A., 2000. Use of carbon dioxide enriched atmospheres in the refrigerated storage (2 degrees C) of salmon (Salmo salar) steaks. European Food Research and Technology 210, 179-188.

Dunlap, P.V., Ast, J.C., 2005. Genomic and phylogenetic characterization of luminous bacteria symbiotic with the deep-sea fish Chlorophtalmus albatrossis (Aulopiformes: Chlorophthalmidae) Applied and Environmental Microbiology 71(2), 930-939.

Dunlap, P.V., Kita-Tsukamoto, K., 2006. Luminous bacteria. In: Dworkin, M., Falkow, S., Rosenberg, E., Schleifer, K.H., Stackebrandt, E. (Eds.) The Prokaryotes: A Handbook on the Biology of Bacteria, vol. 3. Springer, New York, NY, pp. 863-892.

Emborg, J., Laursen, B.G., Rathjen, T., Dalgaard, P., 2002. Microbial spoilage and formation of biogenic amines in fresh and thawed modified atmosphere-packed salmon (Salmo salar) at $2{ }^{\circ} \mathrm{C}$. Journal of Applied Microbiology 92, 790-799. 
Emborg, J., Laursen, B.G., Dalgaard, P., 2005. Significant histamine formation in tuna (Thunnus albacares) at $2^{\circ} \mathrm{C}$ - effect of vacuum and modified atmosphere-packaging on psychrotolerant bacteria. International Journal of Food Microbiology 101, 263-279.

Giraffa, G., Neviani, E., 2001. DNA-based, culture-independent strategies for evaluating microbial communities in food-associated ecosystems. International Journal of Food Microbiology 67, 19-34.

Gram, L., Huss, H.H., 1996. Microbiological spoilage of fish and fish products. International Journal of Food Microbiology 33 (1), 121-137.

Hall, T.A., 1999. Bioedit: a user-friendly biological sequence alignment editor and analysis program for Windows 95/98/NT. Nucleic Acids Symposium Series 41, 95-98.

Hamza, A.A., Robene-Soustrade, I., Jouen, E., Lefeuvre, P., Chiroleu, F., Fisher-Le Saux, M., Gagnevin, L., Pruvost, O., 2012. Multilocus Sequence Analysis- and Amplified Fragment Length Polymorphism- based characterization of xanthomonads associated with bacterial spot of tomato and pepper and their relatedness to Xanthomonas species. Systematic and Applied Microbiology 35, 183190.

Hansen, A.A., Morkore, T., Rudi, K., Rodbotten, M.., Bjerke, F., Eie, T., 2009. Quality changes of prerigor filleted Atlantic salmon (Salmo salar) packaged in modified atmosphere using $\mathrm{CO} 2$ emitter, traditional MAP, and vacuum. Journal of Food Science 74, M242-M249.

Hastings, J.W., Nealson, K.H., 1981. The symbiotic luminous bacteria. In: Starr, M.P., Stolt, H., Trüper, H.G., Balows, A., Schlegel, H.G. (Eds.), The Prokaryotes. A Handbook on Habitats, Isolation, Identification of Bacteria. Springer-Verlag, New York, NY, pp. 1332-1345.

Hovda, M.B., Sivertsvik, M., Lunestad, B.T., Lorentzen, G., Rosnes, J.T., 2007. Characterisation of the dominant bacterial population in modified atmosphere packaged farmed halibut (Hippoglossus hippoglossus) based on 16S rDNA gene-DGGE. Food Microbiology 24 (4), 362-371. 
Janssen, P., Coopman, R., Huys, G., Swings, J., Bleeker, M., Vos, P., Zabeau, M., Kersters, K., 1996.

Evaluation of the DNA fingerprinting method AFLP as a new tool in bacterial taxonomy.

Microbiology 142, 1881-1893.

Joffraud, J.J., Leroi F., Roy, C., Berdagué, J.L., 2001. Characterisation of volatile compounds produced by bacteria isolated from the spoilage flora of cold-smoked salmon. International Journal of Food Microbiology 66, 174-184.

Joffraud, J.J., Cardinal, M., Cornet, J., Chasles, J.S., Léon, S., Gigout, F., Leroi, F., 2006. Effect of bacterial interactions on the spoilage of cold-smoked salmon. International Journal of Food Microbiology 112, 51-61.

Kvitt, H., Ucko, M., Colorni, A., Batargias, C., Zlotkin, A., Knibb, W., 2002. Photobacterium damselae ssp. piscicida: detection by direct amplification of 16S rRNA gene sequences and genotypic variation as determined by amplified fragment length polymorphism (AFLP). Diseases of Aquatic Organisms 48, 187-195.

Lazzi, C., Bove, C.G., Sgarbi, E., Monica, G., La Gioia, F., Sandra, T., Neviani, E., 2009. Application of AFLP fingerprint analysis for studying the biodiversity of Streptococcus thermophilus. Journal of Microbiological Methods 79, 48-54.

Leroi, F., Joffraud, J.J., Chevalier, F., Cardinal, M., 1998. Study of the microbial ecology of coldsmoked salmon during storage at $8^{\circ} \mathrm{C}$. International Journal of Food Microbiology 39, 111-121.

Lévesque, S., St-Pierre, K., Frost, E., Arbeit, R.D., Michaud, S., 2012. Use of Amplified- Fragment Length Polymorphism to study the ecology of Campylobacter jejuni in environmental water and to predict multilocus sequence typing clonal complexes. Applied and Environmental Microbiology 78 (7), 2470-2473.

Macé, S., Cornet, J., Chevalier, F., Cardinal, M., Pilet, M.F., Dousset, X., Joffraud, J.J., 2012. Characterisation of the spoilage microbiota in raw salmon (Salmo salar) steaks stored under vacuum 
or modified atmosphere packaging combining conventional methods and PCR-TTGE. Food

Microbiology 30, 164-172.

Macé, S., Joffraud, J.J., Cardinal, M., Malcheva, M., Cornet, J., Lalanne, V., Chevalier, F., Sérot, T., Pilet, M.F., Dousset, X., 2013a. Evaluation of the spoilage potential of bacteria isolated from spoiled raw salmon (Salmo salar) fillets stored under modified atmosphere packaging. International Journal of Food Microbiology 160, 227-238.

Macé, S., Mamlouk, K., Chipchakova, S., Prévost H., Joffraud, J.J., Dalgaard, P., Pilet, M.F., Dousset, X., 2013b. Development of a rapid real-time PCR method as a tool to quantify viable Photobacterium phosphoreum bacteria in salmon (Salmo salar) steaks. Applied and Environmental Microbiology 79 (8), 2612-2619.

Mougel, C., Thioulouse, J., Perrière, G., Nesme, X., 2002. A mathematical method for determining genome divergence and species delineation using AFLP. International Journal of Systematic and Evolutionary Microbiology 52, 573-586.

Nabhan, S., Wydra, K., Linde, M., Debener, T., 2012. The use of two complementary DNA assays, AFLP and MLSA, for epidemic and phylogenetic studies of pectolytic enterobacterial strains with focus on the heterogeneous species Pectobacterium carotovorum. Plant Pathology 61, 498-508.

Reichelt, J.L., Baumann, P., 1973. Taxonomy of the Marine, Luminous Bacteria. Archiv für Mikrobiologie 94(4), 283-330.

Reynisson, E., Lauzon, H.L., Magnusson, H., Jonsdottir, R., Olafsdottir, G., Marteinsson, V., Hreggvidsson, G.O., 2009. Bacterial composition and succession during storage of North-Atlantic cod (Gadus morhua) at superchilled temperatures. BMC Microbiology 9, 250.

Rudi, K., Maugesten, T., Hannevik, S.E., Nissen, H., 2004. Explorative multivariate analyses of 16S rRNA gene data from microbial communities in modified-atmosphere-packed salmon and coalfish. Applied and Environmental Microbiology 70 (8), 5010-5018. 
Saitou, N., Nei, M., 1987. The neighbor joining method - a new method for reconstructing phylogenetic trees. Molecular Biology and Evolution 4, 406-425.

Savelkoul, P.H.M., Aarts, H.J.M., de Haas, J., Dijkshoorn, B., Duim, M., Otsen, M., Rademaker, J.L.W., Schouls, L., Lenstra, J.A., 1999. Amplified-fragment length polymorphism analysis: the state of an art. Journal of Clinical Microbiology 37(10), 3083-3091.

Sivertsvik, M., Jeksrud, J., Rosnes, J.T., 2002. A review of modified atmosphere packaging of fish and fishery products - significance of microbial growth, activities and safety. International Journal of Food Science and Technology 37, 107-127.

Stohr, V., Joffraud, J.J., Cardinal, M., Leroi, F., 2001. Spoilage potential and sensory profile associated with bacteria isolated from cold-smoked salmon. Food Research International 34, 797-806.

Takahashi, H., Miya, S., Kimura, B., Yamane, K., Arakawa, Y., Fujii, T., 2008. Difference of genotypic and phenotypic characteristics and pathogenicity potential of Photobacterium damselae subsp. damselae between clinical and environmental isolates from Japan. Microbial Pathogenesis 45, $150-158$.

Tamura, K., Stecher, G., Peterson, D., Filipski, A., Kumar, S., 2013. MEGA6: Molecular Evolutionary Genetics Analysis version 6.0. Molecular Biology and Evolution 30 2725-2729.

Tao, Z., Larsen, A.M., Bullard, S.A., Wright, A.C., Arias, C., 2012. Prevalence and population structure of Vibrio vulnificus on fishes from the northern Gulf of Mexico. Applied and Environmental Microbiology 78 (21), 7611-7618.

Thompson, F.L., Hoste, B., Vandemeulebroecke, K., Swings, J., 2001. Genomic diversity among Vibrio isolates from different sources determined by fluorescent Amplified Fragment Length Polymorphism. Systematic and Applied Microbiology 24, 520-538. 
Thyssen, A., Van Eygen, S., Hauben, L., Goris, J., Swings, J., Ollevier, F., 2000. Application of AFLP for taxonomic and epidemiological studies of Photobacterium damselae subsp. piscicida. International Journal of Systematic and Evolutionary Microbiology 50, 1013-1019.

Urbanczyk, H., Ast, J.C., Dunlap, P.V., 2011. Phylogeny, genomics, and symbiosis of Photobacterium. FEMS Microbiology Reviews 35, 324-342.

Urbanczyk, H., Furukawa, T., Yamamoto, Y., Dunlap, P.V., 2012. Natural replacement of vertically inherited lux-rib genes of Photobacterium aquimaris by horizontally acquired homologues.

Environmental Microbiology Reports 4 (4), 412-416.emi4_355 412..416

Vos, P., Hogers, R., Bleeker, M., Reijans, M., van de Lee, T., Hornes, M., Frijters, A., Pot, I., Peleman, J., Kuiper, M., Zabeau, M., 1995. AFLP: a new technique for DNA fingerprinting. Nucleic Acids Research 23, 4407-4414.

Wilson, B., Danilowicz, B.S., Meijer, W.G., 2008. The diversity of bacterial communities associated with Atlantic cod Gadus morhua. Microbial Ecology 55, 425-434. 
Table 1

Table 1. List of isolates and reference strains used in this study with their identification, origin and code. Results of AFLP identification including species and subcluster as well as luxA gene amplification are given in the right columns.

\begin{tabular}{|c|c|c|c|c|c|c|}
\hline $\begin{array}{l}\text { Strain/isolate } \\
\text { ID }\end{array}$ & $\begin{array}{c}\text { Previous } \\
\text { identification }\end{array}$ & Origin & Batch & Code & $\begin{array}{c}\text { AFLP } \\
\text { identification** }\end{array}$ & $\operatorname{lux} \mathrm{A}$ \\
\hline 01 & P. phosphoreum* & Salmon steak & $\mathrm{A}^{1}$ & MIP2423 & P. phosphoreum, Ів & + \\
\hline 02 & P. phosphoreum* & Salmon steak & $\mathrm{C}^{2}$ & MIP2472 & $\begin{array}{l}\text { P. iliopiscarium, } \\
\text { ІІв }_{\text {B }}\end{array}$ & - \\
\hline 03 & P. phosphoreum* & Salmon steak & $\mathrm{C}$ & MIP2473 & P. phosphoreum, Ів & + \\
\hline 04 & P. phosphoreum* & Salmon steak & $\mathrm{C}$ & MIP2478 & 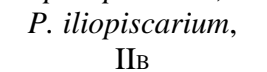 & - \\
\hline 05 & P. phosphoreum* & Salmon steak & $\mathrm{D}^{3}$ & MIP2560 & P. phosphoreum, Ів & + \\
\hline 06 & P. phosphoreum* & Salmon steak & D & MIP2562 & P. phosphoreum, Ів & + \\
\hline 07 & P. phosphoreum* & Salmon steak & & MIP2563 & P. phosphoreum, Ів & + \\
\hline 08 & P. phosphoreum* & Salmon steak & D & MIP2565 & P. phosphoreum, Ів & + \\
\hline 09 & P. phosphoreum* & Salmon steak & $\mathrm{D}$ & MIP2566 & P. phosphoreum, Ів & + \\
\hline 10 & P. phosphoreum* & Salmon steak & D & MIP2567 & P. phosphoreum, Ів & + \\
\hline 11 & P. phosphoreum* & Salmon steak & D & MIP2569 & P. phosphoreum, Ів & + \\
\hline 12 & P. phosphoreum* & Salmon steak & $\mathrm{E}^{4}$ & MIP2583 & P. phosphoreum, Ів & + \\
\hline 13 & P. phosphoreum* & Salmon steak & E & MIP2585 & P. phosphoreum, Ів & + \\
\hline 14 & P. phosphoreum* & Salmon steak & $\mathrm{E}$ & MIP2586 & P. phosphoreum, Ів & + \\
\hline 15 & P. phosphoreum* & Salmon steak & $\mathrm{E}$ & MIP2588 & P. phosphoreum, Ів & + \\
\hline 16 & P. phosphoreum* & Salmon steak & $\mathrm{E}$ & MIP2591 & P. phosphoreum, Ів & + \\
\hline 17 & P. phosphoreum* & Salmon steak & $\mathrm{F}^{5}$ & MIP2605 & P. phosphoreum, Ів & + \\
\hline 18 & P. phosphoreum* & Salmon steak & $\mathrm{F}$ & MIP2607 & P. phosphoreum, Ів & + \\
\hline 19 & P. phosphoreum* & Salmon steak & $\mathrm{F}$ & MIP2609 & P. phosphoreum, Ів & + \\
\hline 20 & P. phosphoreum* & Salmon steak & $\mathrm{F}$ & MIP2611 & P. phosphoreum, Ів & + \\
\hline 21 & P. phosphoreum* & Salmon steak & $\mathrm{F}$ & MIP2612 & P. phosphoreum, Ів & + \\
\hline 22 & P. phosphoreum* & Salmon steak & $\mathrm{F}$ & MIP2613 & P. phosphoreum, Ів & + \\
\hline 23 & P. phosphoreum* & Smoked salmon & 6 & SF955 & P. phosphoreum, Ів & + \\
\hline 24 & P. phosphoreum* & Smoked salmon & 6 & SF1224 & P. phosphoreum, Ів & + \\
\hline 25 & P. phosphoreum* & Spoiled haddock fillet & 7 & EU2181 & $\begin{array}{l}\text { P. iliopiscarium, } \\
\text { ІІв }\end{array}$ & - \\
\hline 26 & P. phosphoreum* & Smoked salmon & 8 & SF686 & P. phosphoreum, Ів & + \\
\hline 27 & P. phosphoreum* & Smoked salmon & 8 & SF684 & P. phosphoreum, Ів & + \\
\hline 28 & P. phosphoreum* & Lyngby, Denmark & 9 & RF44 & P. phosphoreum, Ів & + \\
\hline 29 & P. phosphoreum* & Smoked salmon & 8 & SF680 & P. phosphoreum, Ів & + \\
\hline 30 & P. phosphoreum* & Smoked salmon & 8 & SF714 & P. phosphoreum, Ів & + \\
\hline 31 & P. phosphoreum* & Smoked salmon & 8 & SF723 & P. phosphoreum, Ів & + \\
\hline 32 & P. phosphoreum* & Salmon steak & $\mathrm{G}^{10}$ & $\mathrm{~J} 3 \mathrm{C} 17$ & $\begin{array}{c}\text { P. iliopiscarium, } \\
\text { IIA }_{\mathrm{A}}\end{array}$ & - \\
\hline 33 & P. phosphoreum* & Salmon steak & G & $\mathrm{J} 4 \mathrm{C} 1$ & $\begin{array}{c}\text { P. iliopiscarium, } \\
\text { IIA }^{\text {A }}\end{array}$ & - \\
\hline 34 & P. phosphoreum* & Salmon steak & G & $\mathrm{J} 4 \mathrm{C} 2$ & $\begin{array}{c}\text { P. iliopiscarium, } \\
\text { IIA }_{A}\end{array}$ & - \\
\hline 35 & P. phosphoreum* & Salmon steak & G & $\mathrm{J} 4 \mathrm{C} 3$ & P. phosphoreum, IA & + \\
\hline 36 & P. phosphoreum* & Salmon steak & G & $\mathrm{J} 4 \mathrm{C} 4$ & $\begin{array}{l}\text { P. iliopiscarium, } \\
\text { IIA }_{\mathrm{A}}\end{array}$ & - \\
\hline 37 & P. phosphoreum* & Salmon steak & G & $\mathrm{J} 4 \mathrm{C} 5$ & P. phosphoreum, IA & + \\
\hline 38 & P. phosphoreum* & Salmon steak & G & $\mathrm{J} 4 \mathrm{C} 11$ & P. phosphoreum, IA & + \\
\hline 39 & P. phosphoreum* & Salmon steak & G & $\mathrm{J} 4 \mathrm{C} 12$ & P. phosphoreum, IA & + \\
\hline 40 & P. phosphoreum* & Salmon steak & G & $\mathrm{J} 4 \mathrm{C} 13$ & P. phosphoreum, IA & + \\
\hline 41 & P. phosphoreum* & Salmon steak & G & $\mathrm{J} 4 \mathrm{C} 14$ & P. phosphoreum, IA & + \\
\hline 42 & P. phosphoreum* & Salmon steak & G & $\mathrm{J} 7 \mathrm{C} 1$ & P. phosphoreum, IA & + \\
\hline 43 & P. phosphoreum* & Salmon steak & G & $\mathrm{J} 7 \mathrm{C} 2$ & P. phosphoreum, IA & + \\
\hline 44 & P. phosphoreum* $*$ & Salmon steak & G & $\mathrm{J} 7 \mathrm{C} 4$ & P. phosphoreum, IA & + \\
\hline 45 & P. phosphoreum* & Salmon steak & G & $\mathrm{J} 7 \mathrm{C} 5$ & $\begin{array}{c}\text { P. iliopiscarium, } \\
\text { IIA }\end{array}$ & - \\
\hline 46 & P. phosphoreum* & Salmon steak & G & J7C11 & $\begin{array}{l}\text { P. iliopiscarium, } \\
\text { IIA }\end{array}$ & - \\
\hline
\end{tabular}




\begin{tabular}{|c|c|c|c|c|c|c|}
\hline 47 & P. phosphoreum* & Salmon steak & G & J7C13 & $\begin{array}{l}\text { P. iliopiscarium, } \\
\text { IIA }_{A}\end{array}$ & - \\
\hline 48 & P. phosphoreum* & Salmon steak & G & J7C14 & $\begin{array}{c}\text { P. iliopiscarium, } \\
\text { IIA }_{A}\end{array}$ & - \\
\hline 49 & P. phosphoreum* & Salmon steak & $\mathrm{G}$ & J8C4 & P. phosphoreum, IA & + \\
\hline 50 & P. phosphoreum* & Salmon steak & $\mathrm{G}$ & J8C5 & P. phosphoreum, IA & + \\
\hline 51 & P. phosphoreum* & Salmon steak & $\mathrm{G}$ & $\mathrm{J} 8 \mathrm{C} 11$ & P. phosphoreum, IA & + \\
\hline 52 & P. phosphoreum* & Salmon steak & G & J8C13 & $P$. phosphoreum, IA & + \\
\hline 53 & P. phosphoreum* & Salmon steak & G & $\mathrm{J} 8 \mathrm{C} 14$ & $P$. phosphoreum, IA & + \\
\hline 54 & P. phosphoreum* & Salmon steak & $\mathrm{G}$ & $\mathrm{J} 8 \mathrm{C} 15$ & P. phosphoreum, IA & + \\
\hline $\mathrm{R} 1$ & P. phosphoreum & $\begin{array}{c}\text { (Cohn 1878) Beijerinck } \\
1889\end{array}$ & & CIP102511 & P. phosphoreum, Ів & + \\
\hline R2 & P. phosphoreum & Etelis marshi, Hawaii & & CCUG16288 & P. kishitanii & + \\
\hline R3 & P. iliopiscarium & Pyloric ceca of herring & & DSM9896 & $\begin{array}{l}\text { P. iliopiscarium, } \\
\text { IІв }\end{array}$ & - \\
\hline R4 & P. kishitanii & Marine fish, light organ & & LMG23890 & P. kishitanii & + \\
\hline R5 & P. kishitanii & $\begin{array}{c}\text { Cape Town, South } \\
\text { Africa }\end{array}$ & & CIP104260 & P. kishitanii & + \\
\hline R6 & $P$. angustum & Seawater & & CIP75.10 & & \\
\hline R7 & $\begin{array}{c}\text { P. damselae ssp. } \\
\text { damselae }\end{array}$ & Damsel fish, skin ulcer & & CIP102761 & & \\
\hline R8 & $\begin{array}{l}\text { P. damselae ssp. } \\
\text { piscicida }\end{array}$ & Epizootic of white perch & & CIP103910 & & \\
\hline R9 & $P$. indicum & Marine mud & & LMG22857 & & \\
\hline R10 & P. lipolyticum & Intertidal sediment & & LMG23071 ${ }^{\mathbf{T}}$ & & \\
\hline
\end{tabular}

*tentatively identified $P$. phosphoreum species group as described by Macé et al., 2012, 2013b.

** species, subcluster according to AFLP analysis.

+ presence of luxA gene.

- absence of $\operatorname{luxA}$ gene

${ }^{1}$ Batch A: salmon steak packaged under modified atmosphere, processed in plant I (France) on October 2009 from atlantic salmon (Salmo salar) farmed in Norway.

${ }^{2}$ Batch C: salmon steak packaged under modified atmosphere, processed in plant II (France) on October 2009 from atlantic salmon (Salmo salar) farmed in Norway.

${ }^{3}$ Batch D: salmon steak packaged under modified atmosphere, processed in plant I (France) on Marsh 2010 from atlantic salmon (Salmo salar) farmed in Ireland.

${ }^{4}$ Batch E: salmon steak packaged under vacuum, processed in plant I (France) on Marsh 2010 from atlantic salmon (Salmo salar) farmed in Norway.

${ }^{5}$ Batch F: salmon steak packaged under modified atmosphere in plant II (France) on Marsh 2010 from atlantic salmon (Salmo salar) farmed in Norway.

${ }^{6}$ strains isolated from cold-smoked salmon processed at IFREMER (1996) with different salting and smoking conditions (Leroi et al., 1998).

${ }^{7}$ EU2181: strain isolated from spoiled haddock fillet in Iceland (2003).

${ }^{8}$ strains isolated from cold smoked salmon and identified as described by Leroi et al. (1998) and studied for their spoilage potential by Joffraud et al. (2001) and Stohr et al. (2001). 
9: strain provided by DTU Aqua, Technical University of Denmark.

${ }^{10}$ Batch G: salmon steak packaged under modified atmosphere purchased from a local supermarket (Macé et al., 2013b). 
Figure captions:

Fig. 1. Cluster analysis of the AFLP patterns of isolates and strains using the UPGMA dendrogram generated by the averaged similarity matrix inferred from the three matrices, obtained with the Dice coefficient, corresponding to the three combinations. Cophenetic correlation coefficients and error flags figure at each branch. Main clusters defined at different similarity levels are indicated by brackets. Vertical line corresponding to cut off at $87.1 \%$ similarity delineates clonally distinct isolates. Genotypes: (isolate code) $\mathrm{a}=\mathrm{J} 4 \mathrm{C} 12 ; \mathrm{J} 8 \mathrm{C} 5$; J4C13. $\mathrm{b}=\mathrm{J} 7 \mathrm{C} 2$; J7C4; J7C1. C=MIP2566; MIP2567. $\mathrm{d}=\mathrm{MIP} 2569 ;$ MIP2583. e=MIP2562; MIP2563. f= J4C1; J7C5; J4C2; J7C13; J7C14. g=J3C17; $\mathrm{J} 4 \mathrm{C} 4$.

* species identification according to gyr B gene sequencing.

Fig. 2. Unrooted phylogenetic tree based on neighbor-joining analysis of the $g y r \mathrm{~B}$ gene sequence similarities of the Photobacterium strains and Photobacterium isolates. Strain type sequences of Photobacteriumphosphoreum, Photobacterium kishitanii and Photobacterium iliopiscarium are indicated by a small black triangle. The numbers at branch nodes are bootstrap values shown as percentages of 1000 bootstrap replicates. Only values $>80 \%$ are shown. Scale bar represents $2 \%$ estimated sequence divergence.

Species identification according to AFLP analysis and presence (+) or absence (-) of the luxA gene are indicated on the right-hand side of the brackets. 


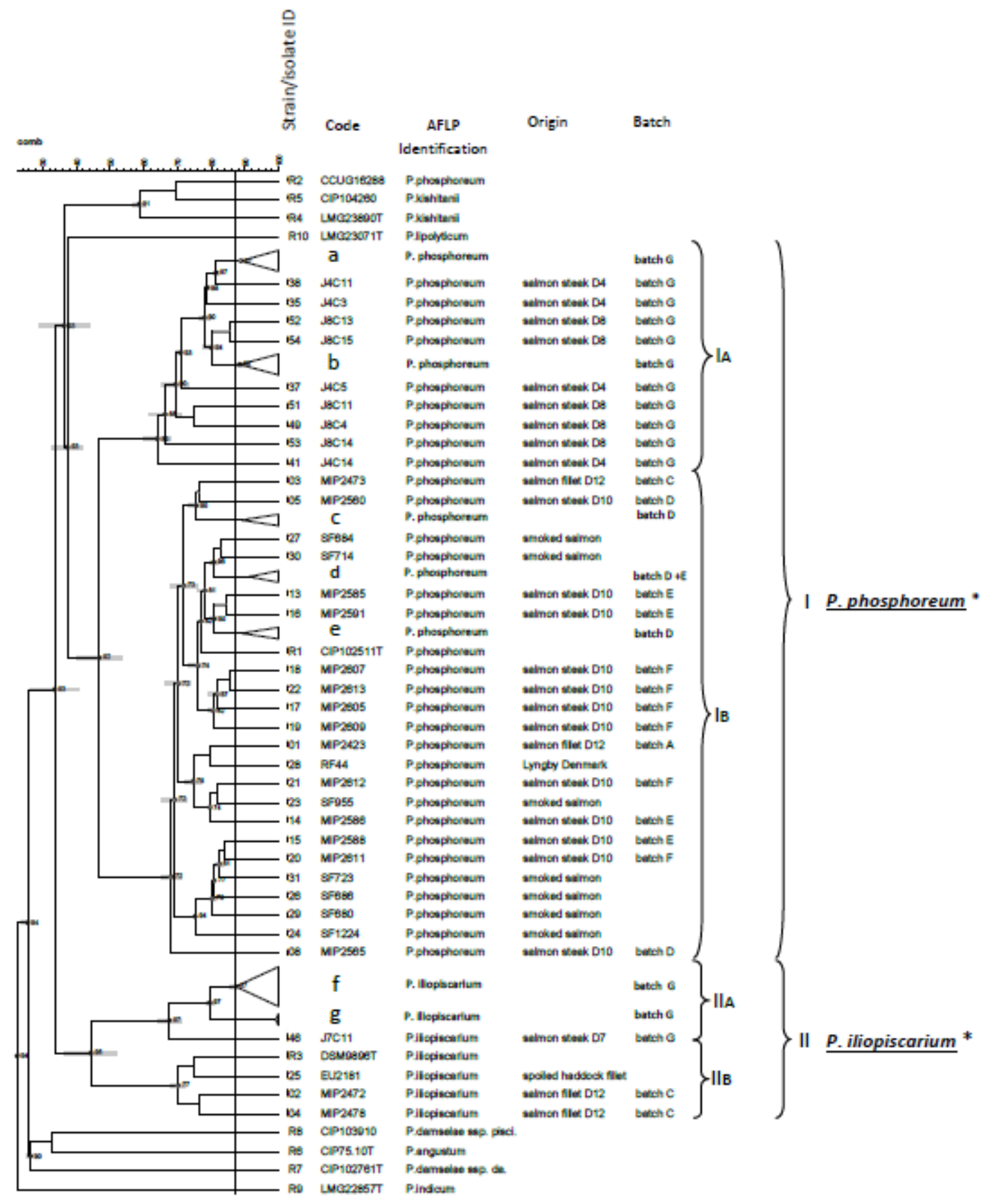

Figure 1. 


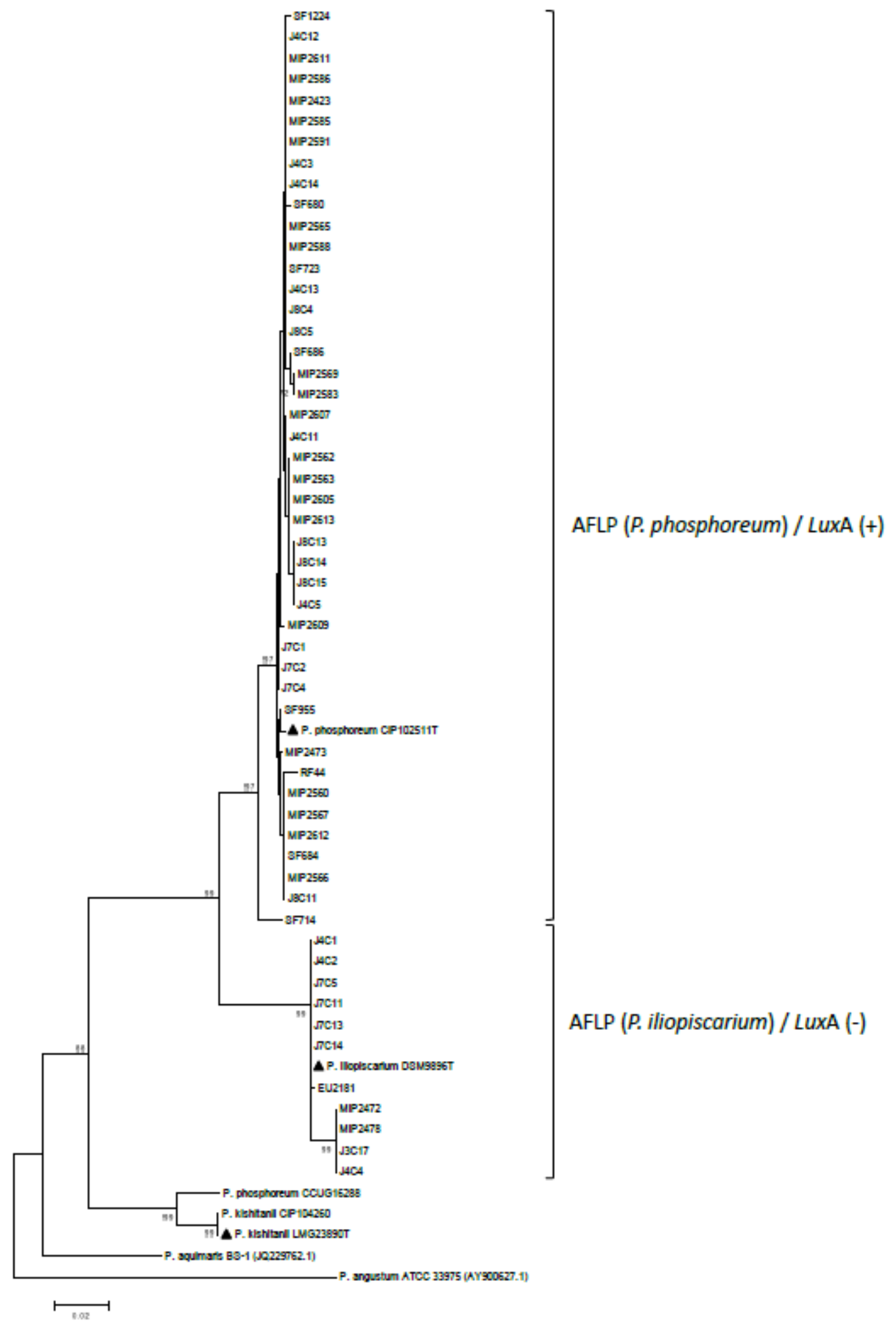

Figure 2. 